\title{
Czułość i wrogość przemian (migracje, reforma rolna i socrealizm w perspektywie „przenośnej rewolucji”)
}

\author{
Andrzej Zieniewicz
}




\section{Czułość i wrogość przemian (migracje, reforma rolna i socrealizm w perspektywie „prześnionej rewolucji”)}

Andrzej Zieniewicz

TEKSTY DRUGIE 2017, NR 6, S. 221-237

DOI: 10.18318/td.2017.6.13

Witold Dąbrowski, poeta, który w owych latach był chłopaczkiem jeszcze, ale już płomiennym komunistą i wielbicielem Majakowskiego, opowiadał mi później, jak groźnie i niebezpiecznie bywało na tym odcinku bitwy klasowej. Wspominał zebranie wiejskie, na które chłopi przyszli z bronią i zatarasowali drzwi... Ja miałam więcej szczęścia: mała dziewczynka podeszła do mnie z gigantycznym workiem gruszek i powiedziała: „Niech pani nie uczy babci czytać. Ona jest taka dobra”.

Agnieszka Osiecka Szpetni czterdziestoletni

\section{1.}

Trzy procesy - reforma rolna, migracje i socrealizm fundamentują, ale i stygmatyzują początek Polski Ludowej, zarówno realny, jak symboliczny. Czynią zeń opowieść głęboko ambiwalentną, naznaczony "skazą" winy styk wyzwolenia i zniewolenia, nadziei i fałszu, ale też czułości i wrogości. Rozważane oddzielnie odsłaniają odmienną idiomatykę przeżyć, ujmowane łącznie dają
Andrzej Zieniewicz profesor w Zakładzie Literatury XX i XXI wieku na Wydziale Polonistyki UW. Wykładał na Uniwersytecie Ankarskim i Uniwersytecie Stambulskim w Turcji, był Dyrektorem Centrum Języka Polskiego i Kultury Polskiej „Polonicum". Zainteresowania badawcze: historia i historiozofia w literaturze $X X$ wieku, problemy literatury jako świadectwa, studia nad formami z pogranicza fikcji i autobiografii. Ostatnia książka: Pakty i fikcje. Autobiografizm po końcu wielkich narracji (2011). 
się zobaczyć jako narracje, a może jedna narracja fundamentalna i zastępcza zarazem, narracja awansu społecznego i narracja wstydu ró w n o c z e ś n i e, w sensie takiej właśnie, dwuskładnikowej i skomplikowanej emocjonalnej odpowiedzi na trudne doświadczenie-wyzwanie historyczne. Wyzwanie, na które odpowiedź mogła/musiała być myślana i jako jedynie słuszna, w perspektywie historycznej (klasowej?), i jako głęboko zawstydzająca, w sensie wspólnotowym (narodowym?), gdy szło o bolesne poczucie zbiorowej niesprawiedliwości, wręcz gwałtu na (dotąd obowiązującym) prawie. W upraszczającym skrócie. Reforma - miała uwłaszczyć klasę chłopską, jednak kosztem dotychczasowych właścicieli ziemskich. Migracje (na Ziemie Odzyskane i do miast) - przeistoczyć wczorajszy „lud” w wyrazistą klasowo zbiorowość robotników i chłopów, lecz wyrazistą na przejętych fabrykach i mieniu poprzednich mieszkańców. A socrealizm był rodzajem programu dla inteligencji (środowisk twórczych), w którym swoją klasową świadomość miała ona wypracować w procesie akceptacji nowej rzeczywistości Polski Ludowej, poprzez jednak radykalne zerwanie z dotychczasową tradycją uprawiania nauki, literatury, publicystyki. Przy czym trudność ulokowania tych przemian w polu wyobrażeniowym nie jest tylko kwestią „prześnienia”, a więc możliwego nieprzyjęcia do wiadomości rewolucji, dokonanej cudzymi rękami, ale kwestią wymuszonego przebudzenia właśnie. „Zbudzono nas, ludzi nie najgorszej woli, albo nas pochowano pod gruzami domu"2 - jak pisał Adam Ważyk. Jako że wszystkie trzy procesy są sy tu a cj a mi gra n i c z ny mi; stawiają ludzi wobec przemocy (ale z jej beneficjami) oraz dzielą ich dramatycznie na uczestników i bystanderów $w^{3}$. Przy czym bystander coś „prześnić” może, uczestnik natomiast - nie, ponieważ dotknięty zostaje losem; a więc nieuchronnością z mi any ki erunku a u to o p owieści, by tak nazwać moment historyczny, w którym trzeba dokonać zasadniczo

1 Odwołuję się tu do pomysłów interpretacyjnych i terminologii Andrzeja Ledera, z jego książki Prześniona rewolucja. Ćwiczenia z logiki historycznej, Wydawnictwo Krytyki Politycznej, Warszawa 2014, względem której jednak logika moich rozważań jest nie tyle „polemiczna", ile skośna, idąca w innym kierunku.

2 A. Ważyk Szkic pamiętnika, w: tegoż Wiersze wybrane, Czytelnik, Warszawa 1982, s. 103.

3 Kategorię bystander stworzył Raul Hilberg na oznaczenie biernego świadka Zagłady. Wydaje się, że pojęcie to (jego krytykę przeprowadziła Elżbieta Janicka, Mord rytualny z aryjskiego paragrafu. O ksiq̨żce Jana Tomasza Grosa "Strach. Antysemityzm w Polsce tuż po wojnie. Historia moralnej zapaści”, "Kultura i Społeczeństwo” 2008 nr 2, s. 238 - za którą je wprowadzam) daje się rozszerzać na inne niż Zagłada doświadczenia graniczne, a także rozumieć (krytycznie) w pewnej analogii do „prześnienia” Andrzeja Ledera. 
nowego samookreślenia, lub prościej - zacząć myśleć o sobie zupełnie inaczej. Borowski mówi w wojennym wierszu: „Gdziekolwiek ziemia jest snem, tam trzeba dośnić do końca" ${ }^{4}$, mając na myśli takie doświadczenie, którego graniczność polega przede wszystkim na odarciu ze złudzeń. Jest to bowiem moment, gdy (zbudujmy taki skrót interpretacyjny) lacanowskie Realne zaczyna być widoczne gołym okiem i wcale niełatwo je przesłonić jakąś chroniącą niewiedzą symboliczno-wyobrażeniową, gdy plan rzeczywistości historycznej przekłada się b e z p o ś r e d n i o na indywidualną biografię, a historia nie dzieje się gdzieś w anonimowości „procesów” ani w pałacach wielkich stolic, ale wdziera się w świat osoby i w nim rozgrywa, odzierając po drodze tę osobę ze wszystkich iluzji, pociech i mityzacji. Słowa nie potrafią sprawozdać tej ostateczności, gdy z hurgotem zatrzaskują się drzwi wagonu repatrianckiego pociągu ruszającego na zachód. Albo gdy geometra kroczy z drewnianym cyrklem przez obmierzane pole, za nim dwaj żołnierze z pepeszami, a w tle stacyjka na Ziemiach Odzyskanych, wojskowe ciężarówki rozwożące przesiedleńców po nowych siedliskach, i transparent: „Wracamy na ziemie Piastowskie". To są obrazy jednocześnie czułe i wrogie, nasze i obce, ale przede wszystkim - n i e o d w o ł a l n e. Jesteśmy wobec nich uczestnikami albo bystanderami, którzy niewiele rozumieją. A zwłaszcza nie rozumieją, że one są j e d n o c z e ś n i e wyjściem z wojny, jakby rozpoczęciem zabliźniania ran okupacyjnych, ale i straszną powszechnością przymusu, nakazu. I w obrazach reformy czy przesiedleń ta jednoczesność obu elementów nowej rzeczywistości, ziemi i władzy, albo szerzej, wła s n o ś c i i pr ze mo cy, jest zawsze widoczna. Stanowi ich stygmat.

Wspólnym mianownikiem reformy i migracji (a w pewien sposób także socrealizmu) jest to, że terytorialność (lokalność) została w nich w znacznym stopniu przejęta i zastąpiona przez strukturę państwową, a więc przez typ więzi i poczucie przynależności instytucjonalnej. Chłop „nadzielony” i emigrant "nasiedlony” uwłaszczał się, nie tylko na ziemi zresztą, ale i na dobytku, mieszkaniu, posadzie, wykonywanej pracy - lecz uwłaszczał się w znacznym stopniu jako beneficjent i uczestnik władzy ludowej. A podobne procesy „uwłaszczenia”, skolektywizowania, zinstytucjonalizowania, „usłusznienia” świadomości, zachodziły wszak w twórczości autorów angażujących się z rozmachem w pisarstwo socrealistyczne. Miały one rozmaity charakter, niekoniecznie od razu zniewolenia umysłu, przykładem choćby ogromna - po wojnie - potrzeba życia i pracy w bezpieczeństwie, na terenach

4 T. Borowski Obrazy snu, w: tegoż Utwory zebrane, t. 1, PIW, Warszawa 1954, s. 135. 
czy w miastach i fabrykach należących do Polski. Lecz to „bycie na swoim” istniało nie inaczej jak poprzez nadrzędną strukturę sankcjonującej je władzy, co pojmowano tym jaśniej, im lepiej zdawano sobie sprawę z uczestniczenia w procesie wymiany własności, ziemi, domów, przestrzeni miejskiej, organizmu urbanistycznego, których migranci stawali się kolejnymi użytkownikami, gdy po poprzednich jeszcze ślady nie wystygły, krew nie obeschła, jeszcze ich wywożą, tak jak nas przywieźli... Rozparcelowani właściciele, podobnie jak wypędzani Niemcy, są tu milczącym Innym, podlegającym resentymentowi i mającym na mocy ideologii pozostać poza opowieścią, w jej didaskaliach "sprawiedliwości historycznej”. Tyle że to „poza” stawało się zbyt obszerne, by zmieścić je w przypisach. Wiosną i latem 1945 roku na Ziemiach Odzyskanych dantejskie sceny były codziennością ${ }^{5}$ - wysiedlanie Niemców i tzw. dzikie wypędzenia, i porażka akcji wysiedleniowych (w połowie roku 1945 akcję wysiedlania Niemców wstrzymano), samowola i rabunki administracji Armii Czerwonej, wywózki setek fabryk, maszyn, bydła, konflikty sowieckie z polską komendanturą, słabiutkie grupy operacyjne tworzonej polskiej administracji, a także gehenna przyjezdnych, emigrantów zabużańskich, z Białorusi, z Podola, ich pamięć okupacyjnej przeszłości, rzezi wołyńskiej, strachu przed banderowcami, porażenia radzieckimi wywózkami jeszcze w 1944 roku - to wszystko, jeśli miało być „poza” świadectwem, jako tematy tabu, to uniemożliwiało je w ogóle, lecz znowu w zapisie zbyt szczegółowym trudno było o przetworzenie skomplikowanych kolei losu w jakiś nadrzędny motyw, dający poczucie oparcia tożsamości. Tworzyło to sytuację, w której ten spójny motyw (ideologiczny) okazywał się niezbędny, by u d ź w i g n ą ć rzeczywistość. Inaczej mówiąc, autoopowieść ideologicznie poprawna była zupełnie niewiarygodna, ale równie niewiarygodne byłoby udawanie, że się tej władzy nic nie zawdzięcza. Myślenie, nawet najbardziej potoczne, rozgrywa się tu blisko spraw ostatecznych i w aurze nieodwołalności. Czesław Miłosz, wspominający po latach początki Polski powojennej i jednocześnie, jak powiada, „zstępujący w głąb swoich wstydów”, podkreśla właśnie j e d n o c z e s n ą niemożliwość akceptacji tamtej rzeczywistości, bo wszak była tragedią nieodwołalnego końca dawnej Polski, ale i zupełną jałowość jej „dezakceptacji”, jako sporu z tym, co się już, i to na wielką skalę, stało. „Co

5 Z literatury na ten temat oprócz książki Marcina Zaremby Wielka trwoga. Polska 1944-1947. Ludowa reakcja na kryzys, Znak, Kraków 2012, wymieńmy też Beaty Halickiej Polski Dziki Zachód. Przymusowe migracje i kulturowe oswajanie Nadodrza 1945-1948, przeł. A. Łuczak, Universitas, Kraków 2015. 
się dzieje - pyta za Szestowem - jeżeli stoimy przed wyborem: albo prawda, albo życie? Istnieją całe obszary w dziejach [...] społeczeństw [...], do których zbliżamy się ostrożnie, na palcach. I zwykle nawet zaglądnięcie w prawdę kończy się wycofaniem, bo trzeba się jakoś wewnętrznie urządzić". I dalej: „Do czego zmierzam?" - pyta, mając na myśli cały okres okupacji, wyzwolenia, przesiedleń, reformy, socrealizmu, a więc lata 1939-1956. - „Do odsłonięcia rąbka kurtyny, bo tragedia Polski, mało mająca sobie równych, dotychczas pozostaje zakryta [...]. I niektóre straszne prawdy nie są dotychczas głośno wypowiadane"6. Do tych prawd należy zapewne powszechne wtedy wyczucie, że wielkoskalowe, a to znaczy p o l i t y c z n e „skurcze i rozkurcze historii” są zupełnie obojętne na sprawy małych narodów, albo przesiedlanych plemion, którym nie pozostaje nic poza tym, by wobec tej obojętności jakoś „urządzić się wewnętrznie", a to znaczy - w imię jednej słuszności inną słuszność wyprzeć. Wybudować w sobie zgodę na rzeczywistość, w której przyjęto, co nieodwołalne, a wymazano to, co przeszkadzało w jej akceptacji. Jak to opisał jeden z pionierów Ziem Odzyskanych: „Były to czasy szalonego napięcia, w których całe nasze społeczeństwo żyło jak na rozstajnych drogach, nie wiedząc w którą udać się stronę... Ciężko było samego siebie przekonać, ale mając na myśli dobro powszechne narodu, zrozumiałem, że nie ma innego wyjścia, tylko trzeba iść za władza, która się obecnie w Polsce utworzyła"”.

Ten motyw „samoprzekonywania się" - wychodzenia z sytuacji bycia na rozdrożu przez afirmację nowego kierunku autoopowieści, poszukującej teraz oparcia we wspólnocie ideologicznej, motyw będący może odwrotnością "prześnienia”, tak jak rozumie je Andrzej Leder, jest dla reformy, migracji i socrealizmu znamienny i tworzy charakterystyczne figury dyskursu prozy poświęconej tym tematom. Z jednej strony mamy więc w niej zawsze zjawisko świadomie „zawężanego horyzontu" poznawczego, pewnego stopnia zakłamania, jako przyjęcia oficjalnej perspektywy narzucanej przez państwo, przyjęcia w figurach mniej lub bardziej fanatycznego i fantazmatycznego wmawiania sobie tego, w co się chce uwierzyć, a z drugiej strony szereg zabiegów mających równoważyć ideologiczny przechył, zabiegów konstruowania autentyku przez wstawienie, w miejsce tego, co wymilczane i wymazane, scen, motywów i realiów skądinąd (albo uniwersalnych), mających podżyrować prawdziwość opowieści. Modelowe dla takiej prozy jest np. ukazanie głębokiej historycznej słuszności zasiedlania Ziem Zachodnich, heroizmu

6 C. Miłosz Rok myśliwego, Znak, Kraków 1991, s. 113, 161.

7 Zob. B. Halicka Polski Dziki Zachód, s. 229. 
osadników, ich serdecznej (!) współpracy z radzieckimi komendanturami, autentyk zaś poręczany jest przez np. zręcznie zmontowane sceny pracy armijnych szoferaków, wspominanie o szabrze oraz oczywiście motyw miłości wojskowego do wyjeżdżającej Niemki. To przecież Skąani w ogniu Wojciecha Żukrowskiego, a podobnych powieści, poświęconych zarówno migracjom, jak wprowadzanej reformie rolnej, na przełomie lat 40. i 50. ukazuje się sporo ${ }^{8}$. Wytwarzają one autentyk zbudowany wokół motywu przymusu historycznego, przemocy, władzy, lecz tak ukazanej, by w nim afirmacja wyparła nieodwołalność 9 . W opowiadaniu Wlistopadzie, miesiacu wiosennym Witolda Zalewskiego (z tomu Traktory zdobędą wiosnę) cały, szczegółowo i logicznie skonstruowany plan przedstawienia skomplikowanej klasowo sytuacji wsi - jej faktycznego rozwarstwienia mimo przeprowadzonej reformy, wewnętrznych podziałów na bogatszych, średniaków i biedniejszych, które wychodzą na jaw dopiero w związku z deklarowanymi udziałami (paszą, pracą i siłą koni pociągowych) w zakładanej spółdzielni produkcyjnej - jest właściwie realistyczny i wiarygodny (mimo propagandowych uproszczeń: ksiądz-kułak, dawny właściciel gruntów jako volksdeutsch), a przekłamanie ogranicza się do deus ex machina zebrania partyjnego, które wszystko cudownie naprawia. Gdyby nie ono, opowiadanie byłoby precyzyjnym studium, ukazującym, dlaczego we wsi założenie spółdzielni nie może się udać. Mimo że spółdzielnie się w skali Polski nie udały ${ }^{10}$, bez opisu ich zakładania w ogóle nie dałoby się uchwycić

8 Z literatury o osadnictwie na Ziemiach Zachodnich wymieńmy Natalii Bukowieckiej-Kruszony Rubież (1948, w odcinkach w "Głosie Wielkopolskim"), Anny Kowalskiej Uliczkę klasztorną (1949, 1964), Henryka Worcella Widzę stąd Sudety (1959), Parafian (1960), Najtrudniejszy język świata (1965), Eugeniusza Paukszty Trud nowej ziemi (1948), Wrastanie (1964), Po burzy jest pogoda (1966), Przejaśnia się niebo (1966), Józefa Hena Krzyż walecznych (1964), Zygmunta Trziszki Dom pod białą skarpq (1965).

9 Np. o książkach Henryka Worcella pisze Beata Halicka: „Henryk Worcell przemilcza w swoich książkach kilka problemów [...], przede wszystkim politykę, która od momentu objęcia władzy przez komunistów coraz bardziej odciskała piętno na życiu zwykłych ludzi [...]. Podobnie nie pisze o przyczynach osiedlania się na nowo przyłączonych ziemiach [...]. Prawie w ogóle nie pojawiają się w opowiadaniach Rosjanie - ani czerwonoarmiści [...], ani radzieccy okupanci [...]. [...] zagadnienia te na pewno nie były obce pisarzowi, Henryk Worcell wiedział jednak dokładnie, o czym nie wolno mu pisać". Dalej jednak badaczka zauważa, że były to pominięcia artystycznie zrozumiałe, gdyż szło o świadectwo w opowieści możliwej wtedy do spisania przez jej bohaterów, o realność widzianą ich oczami. „O wyjątkowości tego dzieła przesądza jednak spojrzenie z perspektywy osadników, którzy współtworzyli nową rzeczywistość, stojąc na samym dole drabiny społecznej". B. Halicka Polski Dziki Zachód, s. 68-69.

10 W roku 1956 "Ogromna część spółdzielni produkcyjnych uległa rozwiązaniu, oddaliły się bezpośrednie zagrożenia, których chłop najbardziej się obawiał" - pisze Stefan Nowakowski, Zanik 
procesów, które wieś zaraz po wojnie głęboko przecież przeorały. Realizm tej orki, tych przemian był właśnie "soc" - nie inny. Podobnie dzieje się w Przy budowie Konwickiego. Sceny pracy w wykopach, w barakach „element” przyjezdny z całej Polski, chłopi wymieszani z „miejskimi”, ich gadaniny, kradzieże, marnotrawstwo źle płaconych dniówek (nikt nie potrafi ich policzyć), pamięć okupacji, przedwojnia, awantury urzędników z majstrami, szaleństwo narzucanego z góry "planu”, wódka, inżynierowie z centrali podwijający nogawki, by się nie zabłocić, pierwsze doświadczenia robocze młodego pracownika aparatu partyjnego, szykowne „ubrania szybowe” i kartoflanka gotowana na dymiącym piecyku, wędrówki cwaniaków z budowy na budowę - to wszystko jako realizm nowohucki nie dałoby się w ogóle opisać z perspektywy innej niż afirmatywna, choć jest ona skłamana jako (znowu) deus ex machina zebrania partyjnego. Lecz skłamana w pewnej głębszej, świadomie konstruowanej afirmacji kogoś, kto swym pisaniem „pragnie wstąpić w świętą rzekę losów robotniczych", bo tak się na nowo wymyślił literat Konwicki, który bez tego pragnienia nie opisałby Nowej Huty, gdzie przez dziesięć miesięcy machał łopatą, będąc „kopaczem dołowym, na środkowym poziomie"11.

Można zatem powiedzieć, że ideologiczne identyfikacje bohaterów nie są w tej prozie czymś zewnętrznym, narzuconym, ale k o n i e c z n ą af i r m a c j ą, umożliwiającą pisarskie przedstawienie rzeczywistości, która z pozycji nieafirmatywnych nie dałaby się w ogóle literacko zauważyć, także w sensie braku motywacji pisarskich do wytwarzania przedstawienia. Chcę rzec, schematyzm tej literatury jest kwestią jej uproszczonych (często znacznie) recept wykonawczych, jako pisarskiego udawania, że wie się mniej, niż się wie naprawdę, jednakże jej akceptowany s ch e m at, w sensie rozpoznawania procesu historycznego, który rzeczywistość nakręca i strukturuje, jest sprawą afirmatywnego (wynegocjowanego ze sobą) zaangażowania w tę rzeczywistość, organizującego wyobraźnię pisarza. I napięcia wewnątrz przedstawienia, „skaza” jego niewiarygodności, ujawniają się zawsze na linii między kłamstwem socpropagandy a trudną rzeczywistością reformy, migracji, przebudowy kraju, w sumie jednak akceptowaną. Co zresztą ważne jest także z perspektywy adresu czytelniczego. Omawiane pisarstwo bowiem miało

klasy?, w: Chłop polski. Szkic do portretu, wybór i wstęp J. Socha, posłowie Z. Grzelak, Ludowa Spółdzielnia Wydawnicza, Warszawa 1989, s. 91.

11 T. Konwicki Kalendarz i klepsydra, Czytelnik, Warszawa 1976, s. 50 i n. Zob. też S. Nowicki (S. Bereś) Pół wieku czyśćca. Rozmowy z Tadeuszem Konwickim, Puls, Londyn 1986, zwłaszcza rozdz. Nowe życie. 
być, choćby jako „inżynieria dusz”, nie tylko opisem przemian, lecz aktywnym w nich uczestnictwem, czynem partyjnym na budowie, więc zarówno odpowiedzią na zapotrzebowanie społeczne, jak argumentacją uświadamiającą odbiorcę, a też gwarancją „, bezpieczeństwa ontologicznego" prezentowanej realności - co jest, last not least, także prawdziwą historią tego socrealistycznego pisania o wsi, o migracjach, o początkach budowy i przebudowy kraju, pisania idącego od wizji hegemonicznej, klasowej, przemocowej, propagandowej do jej stopniowego porzucania na rzecz kompleksowego „wrastania”" i tworzenia wieloetnicznych kultur porozumienia. Vide późniejsze powieści Kawalca, Nowaka, Myśliwskiego, Pilota. Można to nazwać walką o dostrzeganie rzeczywistości, toczącą się w tej prozie. Walką pomiędzy wytwarzaniem racji założycielskich a wypieraniem niepokoju, tak że opowieść „samoprzekonująca się" balansuje niejako między stanem podgorączkowym wmawianej sobie „nadsłuszności” ustrojowej a wypieranym i przemilczanym poczuciem ogromu rzeczywistości nieprzedstawionej. Zmyśla czułość, by oddalić wrogość.

\section{2.}

Lecz to z my śla n i e c zuło ś ci, „wstępowanie w świętą rzekę losów robotniczych", piastowski entuzjazm zasiedlania Nadodrza czy słuszne pragnienie rozkułaczania wiejskich bogaczy staje się coraz trudniejsze, gdy ogromna siła przyciągająca (młodzież zwłaszcza, często z najuboższych środowisk wiejskich) do programu reformy, budowania nowej Polski, industrializacji, migracji do miast słabnie w konfrontacji z realnymi doświadczeniami reformy i migracji. Powiedzmy: dla każdej z trzech wskazanych domen tematycznych: dla reformy, migracji i socrealizmu, możemy znaleźć moment, w którym narracja ideologicznej „autoperswazji” załamuje się, bo te doświadczenia zaczynają brać górę nad horyzontem oczekiwań otwieranym przez ideologię $e^{13}$. I sprawą

Jak w tytule znakomitej powieści Eugeniusza Paukszty, ukazującej całą komplikację decyzji życiowych podejmowanych przez osadników, a też ich radzenie sobie z polityką, z dyskryminacją, z presjami ideologicznymi, gdy problemy trudnej afirmacji powojennej rzeczywistości Polski daleko wykraczały poza schematy "pozytywnego zaangażowania”, wstępowania do partii itp.

Dobrze widać to na przykładzie wierszy pisanych w okolicach roku 1950, gdy opiewaną wcześniej, i jakoś możliwą do przełknięcia, radość z odbudowy kraju nakazano - w ramach krytyki "odchylenia prawicowo-nacjonalistycznego" - zastąpić z dnia na dzień wyrazami poetyckiej solidarności z walką narodu koreańskiego albo potępieniem odstępstwa Tity. Tego już nie udało się żadnemu z poetów przetworzyć w "autentyk" uczuciowy i polityczny. Nawet Romanowi Bratnemu. 
zasadniczej wagi dla zrozumienia omawianej literatury, pisanej między 1945 a 1956 rokiem, jest to, że ów wybuch ideowego entuzjazmu, wraz z jego $\mathrm{z}$ a ła $\mathrm{m}$ a n i e $\mathrm{m}$, stanowi przeżycie pokoleniowe ${ }^{14}$ - jednak z trudnością odnajduje się w literaturze, bo wcześniej plakatowo-entuzjastyczne, ex post było zawstydzające i wypierane. Niechęć do późniejszego kontaktowania sięz najbardziej osobistym doświadczeniem zaangażowania socrealistycznego, naznacza często na długie lata twórczość piewców sześciolatki, albo przemian wsi, czy epiki wielkich budów. Jest chorobą bardzo trudnego uświadamiania sobie, że operacje autoperswazyjne, mające wyprzeć wątpliwości (ideologiczne), prowadziły do wypierania czy wyrzekania się tożsamoś c i, i do przemiany autora w posłusznego wykonawcę partyjnych dyrektyw które zresztą w ciągu niespełna dwóch, trzech lat okazały się „wypaczeniami”. Adam Ważyk, jeśli wierzyć Adolfowi Rudnickiemu, nigdy nie chciał nawet zbliżyć się w rozmowach do tematu swego nawiedzenia marksistowskiego ${ }^{15}$. Aleksander Wat w rozmowie z Czesławem Miłoszem wspomina o walce, jaką toczył ze sobą Borowski, szukający w radykalnym marksizmie recepty na chorobę obozową ${ }^{16}$. Tadeusz Konwicki dopiero po ćwierćwieczu zdobył się na opowiedzenie o stanach wmawianego sobie fanatyzmu, jakie na przełomie lat 40. i 50. przeżywał17. Czemu trudno się dziwić, bo są to przeżycia i doświadczenia z piekieł XX stulecia, które jednak musiał relacjonować nie $\mathrm{z}$ chętnie

14 Pokoleniowe, a może pokoleniowo-rodzinne, jeśli brać pod uwagę postpamięć, dziedziczenie trudnych emocji oraz pragnienie rekonstruowania porwanej przez wojny i przełomy historyczne "substancji familijnej", substratu pamiętanej przeszłości, w którym osadza się poczucie tożsamości osobowej. Przeżycie - do tej pory uwikłane w dialektykę pamięci (czułości) i wstydu. W numerze 1/2016 „Tekstów Drugich” pt. Powrót pokolenia? Agnieszka Mrozik w szkicu Dziadek (nie) był komunistą. Między/transgresyjna pamięć o komunizmie w polskich (auto)biografiach rodzinnych po 1989 roku pisze o badaniach pamięci rodzinnej: „niejako pod prąd obowiązującej narracji heroicznej, zakładającej bohaterską walkę Polaków z nazizmem i komunizmem, polskie rodziny twierdzą, że tylko się wszystkiemu przyglądały. Ponad 90 procent rozmówców zadeklarowało, że i oni, i ich krewni w ogóle nie interesowali się polityką [...] Krewnych, o których z całą pewnością wie się, że byli w partii czy w milicji, nie traktuje się jak «czarnych owiec»; raczej tłumaczy się ich zachowania koniecznością: «zostali zmuszeni», «nie mieli wyboru» (w roli przymuszających funkcjonują zwykle «oni», «inni», «klika» - naziści, komuniści)", s. 47. Trudno o jaśniejsze świadectwo zakłopotania przeszłością przyswajaną w mieszanych afektach jednoczesnej afirmacji i wstydu.

Zob. A. Rudnicki Krakowskie Przedmieście pełne deserów, PIW, Warszawa 1986, s. 77-78.

Zob. A. Wat Mój wiek. Pamiętnik mówiony, Czytelnik, Warszawa 1990, t. 1, s. 138. 
przyjmowanej perspektywy ofiary. Przeciwnie, wymagało to przyznania się do chętnie zapominanej łatwości ulegania pokusom radykalnych ideologii, doktrynom, fanatyzmom, oszołomieniu, apodyktyczności „lepszej wiedzy”; odrzucania skrupułów; wreszcie chęci bycia aktantem terroru i przemocy. W jednym z wierszy Adam Ważyk mówi o tym, żeby nie zapalać zapałki na strychu swej pamięci. „Zobaczysz las posągów / patos na miarę kołtuna / pajęczynę grozy / i narzędzia mokrej roboty. / Zapałka w palcach parzy jak wstyd"18.

Jednakże doświadczenie wstydu za to, co wmówiliśmy sobie jako opokę słuszności, a co za chwilę okazało się aktem ideologicznego samodurstwa, wstydu za to, że - jak powiedział o swoich latach socrealistycznych Mrożek „ktoś zrobił ze mnie durnia, i że ten ktoś, to ja sam”"19, spowodowało zupełne wyciszenie dyskursu ekspiacji, zastąpionego zrzucaniem winy na „onych”, a też chętną absurdalizację całej problematyki, zneutralizowanie jej (może konieczne) w śmiechu. Jak w Słoniu Mrożka: „Kierownik ogrodu zoologicznego okazał się karierowiczem". Tyle że ów śmiech późniejszy, z socrealizmu, z migracji „wsioków” do miast, z reformy, jawi się jako bardzo drobnomieszczańska (kołtuńska właściwie) reakcja bystandera, który nie widzi, że całe pokolenie Polaków „ze wsi, z miasteczek” w latach 1945-1956, w entuzjazmie wiary i samokształcenia, w biedzie i rzeczywistym awansie, pracowicie nabywało światopogląd, który następnie z hukiem zawalił im się na głowy. Była to polska rewolucja, w której "prześnienie” wierzę z trudem, choćby przez pamięć doświadczeń własnej rodziny, w kwestii zaś niewypracowanego imaginarium tej rewolucji, to owszem, wypracowano je, jeszcze jakie - tylko do dzisiaj się tego wstydzimy. I opowieści środowiska literackiego czy naukowego, snute do późnych lat 80., o branych i rzucanych legitymacjach partyjnych, a też chętne wypominanie późniejszym działaczom opozycji demokratycznej ich wcześniejszej, socrealistycznej przeszłości - do tego „zawstydzonego imaginarium" odnoszą. Podobnie jak wymilczanie krewnych z SB czy dziadków budowniczych Nowej Huty. Lata 50. bowiem, z ich stylem ruin, budów, zaangażowania („Patrz, jak stoi uparta na rusztowaniach Partia”20),

18 A. Ważyk Zapałka, w: tegoż Wiersze wybrane, s. 139. Warto może dodać na marginesie, że w poetyckim języku Adama Ważyka błysk zapalanej zapałki to poezja, gdy zapałka wypalona to proza.

19 Zob. S. Mrożek Baltazar. Autobiografia, Oficyna Literacka Noir sur Blanc, Warszawa 2006, S. $185-186$. 
masowych pieśni, pierwszomajowych pochodów, współzawodnictwa pracy, plakatowego optymizmu, wznoszonego Pałacu Kultury i Nauki, są w pamięci (już kulturowej) wciąż obecne, lecz - jak w filmie Wajdy o człowieku z marmuru - są w tej pamięci zbiorowej gł ę b oko u to pi o n e. Poddają się nie tyle ujawnieniom, ile napomknieniom, bo odnoszą do wydarzeń traumatycznych i zawstydzających, a nie przepracowanych. Nie przepracowanych rozmaicie, ponieważ jeśli w prozie o Ziemiach Zachodnich przejście od wymuszanego entuzjazmu do odreagowania go (poprzez "wrastanie" narracji w głębiej autentyczną i wieloetniczną rzeczywistość) dokonuje się dość powoli, to w narracji o reformie rolnej, i o migracji do miast, następuje skokowo, w okolicach przed rokiem 1956, a po 1949. Widać to w załamaniach powieści produkcyjnej (jej bohater jest często migrantem ze wsi prosto na budowę), lecz jeszcze wyraźniej w dobrej prozie chłopskiej, powstającej wszak, pod piórami Pilota, Nowaka czy Kawalca, dopiero w końcu lat 6o. Czemu tak późno? Ponieważ przepracowanie wstydu, traumy, konfuzji po niefortunnym zaangażowaniu, jako kolejna zmiana kierunku autoopowieści, czyli konieczność dokonania przebudowy wewnętrznej „w drugą stronę” wymagała czasu. Konwicki osiem lat milczał po Władzy, zanim rozliczył swoją wcześniejszą socparadę Sennikiem wspótczesnym. Dla wielu zaś autorów (jak Ważyk) to, co pisali przed rokiem 1956, do końca życia pozostało tematem tabu albo (jak dla Andrzejewskiego) tematem długoletnich metaforycznych tłumaczeń i usprawiedliwień. Lecz, co najważniejsze, przebudowa „w drugą stronę" nie oznaczała powrotu do przekonań wcześniejszych (cokolwiek to znaczy). Oznaczała za to przejście ideowego rozczarowania w poczucie przewagi politycznej socjotechniki nad autentycznym (choćby wmawianym sobie) z a ang a ż ow a n i e m.

O jak zasadniczą sprawę tu idzie, ukazuje fragment, jeśli nie kluczowy, to najczęściej cytowany, z Poematu dla dorostych:

Ze wsi, z miasteczek wagonami jadą zbudować Hutę, wyczarować miasto, wykopać z ziemi nowe Eldorado, armią pionierską, zbieraną hałastrą, tłoczą się w szopach, barakach, hotelach, człapią i gwiżdżą w błotnistych ulicach: wielka migracja, skudlona ambicja, na szyi sznurek - krzyżyk z Częstochowy, trzy piętra wyzwisk, jasieczek puchowy, 
maciora wódki i ambit na dziewki, dusza nieufna spod miedzy wyrwana, wpół rozbudzona i wpół obłąkana, milcząca w słowach, śpiewająca śpiewki, wypchnięta nagle z mroków średniowiecza masa wędrowna, Polska nieczłowiecza [...] Wielka migracja przemysł budująca, nie znana Polsce, ale znana dziejom, karmiona pustką wielkich słów, żyjąca dziko, z dnia na dzień i wbrew kaznodziejom w węglowym czadzie, w powolnej męczarni z niej się wypala robotnicza klasa.

Dużo odpadków. A na razie kasza. ${ }^{21}$

Poemat... to, najdosłowniej, opowieść o skręcaniu się ze wstydu i o próbach (nieudanych) swoistego working through, więc o rozczarowaniu, bolesnym "przejrzeniu na oczy”, o trudności odkłamywania się, o „onych”, którzy "nas” zdemoralizowali oszukańczą dialektyką („Mój rękaw jest słuszny, mój guzik niesłuszny"), o doznanym poczuciu zagubienia, gdy kłamstwem okazuje się marksistowski katechizm („dajcie mi stary kamyczek, niech się odnajdę w Warszawie") - lecz tym, co Ważyka najsilniej żenuje, jest sam rozpad obietnicy socrealizmu, mający dlań wymiar katastrofy ideologicznej. Przeczucia, że w tyglu wielkich budów (ani w reformie, ani w migracjach) żadna stal się nie hartuje, a dojrzała ideowo „robotnicza klasa”, zdolna jutro przejąć ster władzy z rąk dziś rządzących, „się nie wypala”. No to co się wypala? Ważyk przesuwa odpowiedź w plan „na razie”, jakby nie chcąc przyznać, że nadzieje pedagogiki wielkich budów spełniają się, jeśli w ogóle, to opacznie, produkując zamiast przodowników pracy osobliwą formację migrantów ze wsi i z budowy na budowę, chłoporobotników zasiedlających baraki i bursy, pracujących dorywczo, koczujących właściwie, pół wykolejonych, pół zagubionych, między porzucaną (z trudem) chłopskością, a „marginesem społecznym” (wątpliwej) nowoczesności. Na drugim zaś biegunie tej pedagogiki rozkwitał typ działacza, który „zahaczał się” w aparacie partyjnym i państwowym, traktując budowę jako szczebel do kariery administracyjnej czy politycznej. Dyskusje o chuligaństwie i o karierowiczach, przetaczające się przez prasę tamtych 
lat (choćby publicystyczne odpowiedzi na Poemat dla dorostych) ${ }^{22}$, dają świadectwo, że zjawiska te były dostrzegane, choć cenzura uniemożliwiała ich łą c zną artykulację.

W każdym razie, już w latach 1954-1956 widoczne było, że wytop się nie udał, i jak przesiedleńcy nie stali się heroicznymi neokolonizatorami „ziem Piastowskich", tak rzesza chłopskich budowniczych hut i miast nie przeistoczyła się w uświadomionych klasowo, a to znaczy: ideologicznie zaangażowanych robotników; pozostała „,kaszą", ,wypchniętą nagle z mroków średniowiecza”, „półrozbudzoną i półobłąkaną” w przyswojonej byle jak mieszance marksistowskiej politgramoty i nabywanych umiejętności „bycia działaczem”. A w roku 1956 „kaszy” tej z dnia na dzień ogłoszono, w gazetach i przez radio, że to, co do wczoraj było czułe, choć szorstkie, dziś jest obcością okresu błędów i wypaczeń.

Efektem był szok, dezorientacja, ale też co najmniej nadwątlenie (nawet tych wmawianych sobie) przekonań o „jedynej słuszności” powojennych przemian Polski. Głoszone wtedy hasło "socjalizm - tak, wypaczenia - nie” w części o wypaczeniach odnosiło się wszak do zauważonego już (i to od dłuższego czasu) stylu życia aparatu partyjnego, do sklepów za żółtymi firankami, do wszechwładzy „towarzyszy z Bezpieczeństwa”, a ujawniało się też wielu, co sprytniejszym, jako kierunek aspiracji życiowych i realna, a nie plakatowa nadzieja na awans i dobrobyt ${ }^{23}$.

W październiku '56 pada dużo pytań. Piotr Nesterowicz w świetnym reportażu rekonstruuje je z pamiętników młodzieży tamtych lat:

Siedem lat temu Gomułka został odsunięty za odchylenie prawicowo-nacjonalistyczne, a w 1951 trafił do aresztu. Trzy lata później go

22 Informacje o nich w: T. Drewnowski Próba scalenia. Obiegi, wzorce, style, PWN, Warszawa 1997, s. 132. Tamże informacja o artykule Henryka Markiewicza Ćwierćwiecze "Poematu dla dorosłych", „Polityka” $1988 \mathrm{nr} 31$.

Sławomir Mrożek w autobiografii wspomina, że już w gimnazjum wielu uczniów „zaczęło dawać znaki" rozpoznające układ, i niektórzy doszli aż do stanowisk członków KC. Sam debiutował znacząco reportażem z Nowej Huty pisanym z doskonałą znajomością tezy, że (zgodnie z formułą Stalina) walka klasowa zaostrza się przed samym zwycięstwem - i oto chcący pracować w sobotę ZMP-owcy natknęli się na zmowę inteligenckiej, a w istocie reakcyjnej administracji, która nie pozwoliła wydać łopat z magazynu. Jednak zdecydowana postawa aktywu, demonstracja przed biurem, wystraszyła oportunistów, łopaty wydano, rewolucja zwyciężyła, „i niech wre robota, co tam wolna sobota”. Mrożek pisze, że po tym reportażu starsi ludzie zaczęli uważnie przyglądać mu się w kawiarni. Kto to jest? Zob. S. Mrożek Baltazar. Autobiografia, S. 112-118. 
wypuszczono, a trzy dni temu wybrano na pierwszego sekretarza. Co się dzieje? Czy będziemy nadal utrzymywali stosunki polityczne, gospodarcze i kulturalne ze Związkiem Radzieckim? Dlaczego pod Warszawą stoją wojska radzieckie? Czy upaństwowione majątki obszarnicze zostaną zwrócone właścicielom? Jak będziemy budować polski socjalizm? ${ }^{24}$

Zauważmy; są to pytania, co ze sobą zrobić, w jaki sposób na nowo „urządzić się" wobec życia - pytania tym ważniejsze, że odwilż była jednak programem przemian (ale politycznych, nie ideowych) - Władysław Gomułka odwołał pięćdziesięciu sekretarzy komitetów wojewódzkich, trzydziestu członków i zastępców członków KC. Zredukował niższy i średni aparat partyjny. Dziesięć tysięcy aktywistów i urzędników z komitetów powiatowych i miejskich straciło pracę. To samo (proporcjonalnie) dotyczyło Urzędów Bezpieczeństwa ${ }^{25}$. Sylwetka nauczyciela historii w małym miasteczku nad Sołą (Sennik wspótczesny Tadeusza Konwickiego), przed laty będącego działaczem stalinowskim, jest modelowa dla tej, zaniemówionej po październiku przeszłości, podobnie jak modelowa jest sylwetka chłoporobotnika, z awansu kierowanego na coraz wyższe stanowiska w aparacie partyjnym i państwowym. Nowa Huta „urządzała się" jeszcze raz, po kryzysie październikowym, tyle że teraz autoperswazja akcentowała umiejętności socjotechn i c z n e. „Jedynej słuszności” bowiem nie zarzucono, raczej ją wymilczano, zastępując po cichu dawną pryncypialność pragmatyzmem, dążeniem do stabilizacji (gospodarki i nastrojów społecznych) i uznaniem „zdobyczy Polski Ludowej". Angażować należało się już tylko o tyle, o ile było to potrzebne do awansu w przestrzeni nacechowanej politycznie, i poczucie zdrady własnego rodowodu chłopskiego jest często kryptonimowe dla wygaszenia wcześniejszego zaangażowania i zamiany go na karierę polityczną. Przymierzający jaskółkę dyplomaty chłop-dyrektor, już wysyłany na placówkę, wcale nie tęskni za wsią; myśli teraz o tym, jak urządził się drugi raz, gdy wcześniej wyszedł ze wsi jako junak Służby Polsce albo migrant na budowę.

Nocą siedzę przed lustrem,

ja w cylindrze, ja boso,

P. Nesterowicz Każdy pozostał człowiekiem, Wydawnictwo Czarne, Wołowiec 2016, s. 153. zwłaszcza rozdz. Sekretarz ludowy. Zob. też P. Kenny Budowanie Polski Ludowej. Robotnicy a komuniści 1945-1950, przeł. A. Dzierzgowska, Wydawnictwo W.A.B., Warszawa 2015. 
a tam we wsi z wesela

z nożem w plecach mnie niosą. ${ }^{26}$

Dyrektor Toporny, bohater Tańczącego jastrzębia Juliana Kawalca, też musiał (o czym jednak książka nie mówi) przejść trudną drogę awansu politycznego, zanim mógł sobie pozwolić na nostalgię za wiejską młodością. Ten wątek „urządzania się" jest ważny i prawie nie opisany, ponieważ badacze wskazują, że awans społeczny chłopów i robotników dokonywał się na drodze - ku inteligencji ${ }^{27}$. Owszem, ale że ta droga prowadziła nie tylko przez uniwersytety, lecz także przez szkolenia, kursy aktywu, szkoły partyjne, „działaczowanie” w aparacie, przez różne przejścia od „pracy partyjnej” do ministerstw - o tym się raczej nie pisze. Tymczasem ta droga do służbowych mieszkań socjalistycznej klasy średniej wiodła ku „wrastaniu” w nową wspólnotę etnokulturową, w „pokoleniowo-rodzinną" klasę zarządców PRL-u, w socjalistyczne administrowanie, gdzie żarliwość ideologiczna nie jest już wymagana, a przeciwnie, zastępowana poczuciem „bycia swoim”, legitymacją partyjną i umiejętnościami poruszania się w środowisku politycznej biurokracji. I to jest konsekwencją roku 1956. Rozpadający się marksizm stalinowski nie wykształcił bowiem żadnej innej wersji ideologii zaangażowania, trwał w mieszaninie niedopowiedzeń i przekonań pragmatyczno-socjotechnicznych. Dzielił (wektorowo) niedawnych migrantów na wykorzenionych i aparatczyków. Ważyk mówi: „dużo odpadków, a na razie kasza” - właściwym wytopem Nowej Huty była jednak kasza ze skwarkami.

Podobne procesy zachodzą w literaturze. Cytowany wiersz Nowaka nie jest już socrealistyczny, ponieważ po kryzysie Października '56 zrezygnowano z narzucania utworom określonej poetyki, tj. robotniczo-chłopskich obrazów na majakowskich schodkach, tak jak w propagandzie zrezygnowano ze stalinowskich wzorów edukacji społecznej, z klasową, a nie narodową historią, z triumfami ateizmu i nauki radzieckiej na czele. I nie tyle zrezygnowano, ile zawieszono je w stanie połowicznej niedorealizacji; były niby dalej obowiązkowe, ale w istocie wymilczane. W podobny sposób socrealizm kończył

T. Nowak Psalm o nożu w plecach, w: tegoż Psalmy, Wydawnictwo Literackie, Kraków 1971, s. 13.

Np. B. Gołębiowski Bez uprzedzeń i skrajności, w: Chłop polski... pisze: „chłopi znosili dość biernie lata administracyjnego uspółdzielczenia (1950-54), obowiązkowych dostaw itp., nie podnosząc protestów nawet w czasie kryzysów 1956 czy 1970, gdyż wszystko to rekompensowało w sumie zatrudnienie «z awansem» w przemyśle dużej części klasy oraz możliwość awansu przez naukę do warstwy inteligencji", s. 99-100. O napięciach politycznych tego awansu - ani słowa. 
sięjako poetyka, ale nie jako zespół wymagań instytucjonalnych stawianych literaturze. I w tym samym kierunku, czyli przez zastępowanie postulatów inżynierii dusz kompilacją niedomówień szły tłumaczenia kryzysu ideologicznego. „Partii nie obchodzi warsztat pisarzy, ale społeczno-polityczne i ideologiczne poglądy autorów", stwierdzał Władysław Gomułka na Zjeździe ZLP w Lublinie w 1964 roku $^{28}$. Co było też „wersją oficjalną" odpowiedzi na pytanie o błędy i wypaczenia. Polegały one na tym, sugeruje wystąpienie I sekretarza, że tak jak pisarzom chciano narzucić jako obowiązkową majakowską strofę albo "produkcyjne" recepty na powieść (gdy nas to "nie obchodzi”!), tak całej Polsce narzucano przed rokiem 1956 schematyczną, wzorowaną na radzieckiej historię, z której rodacy nie mogli być dumni, w której nie dowartościowano wysiłku zbrojnego GL i AL oraz $\mathrm{BCH}$, i ocenzurowano (niesłusznie) Armię Krajową i pamięć o powstaniu warszawskim... Jesteśmy już w klimacie Siedmiu polskich grzechów głównych Zbigniewa Załuskiego, z ich domyślnym pytaniem: kto mianowicie narzucał? W klimacie pytań, na które odpowiedzi udzielone zostaną, jak wiemy, już w całkiem socjotechnicznym i pragmatycznym trybie walki politycznej między frakcjami puławian i natolińczyków, przy czym głównym specjalistą od oskarżania „winnych" stalinowskiemu schematyzmowi okaże się Mieczysław Moczar, a wyjściem z kryzysu miał być tzw. narodowy komunizm² ${ }^{29}$.

Reforma, migracja, socrealizm traciły ostatnie resztki czułości, określane przez Agnieszkę Osiecką jako „lojalność wobec PRL-u”30 - może najtrwalszy albo jedyny trwały motyw ideologiczny pokolenia '56. Lojalność chyba ostatecznie przekreśloną, gdy zainfekowany narodowym faszyzmem system zaprzeczył sam sobie i został skontestowany jako całość. W opowieści o Sierpniu '8o Adolf Rudnicki przedstawia już pisarzy partyjnych, w tym siebie, jako dworaków, którzy ze snu zaangażowanej młodości „obudzili się na dworze księcia”, a o partii pisze, że „samej sobie zadała cios w roku 1968; towarzyszom Żydom przypomniano, kim są. [...] Lata 1980, 1981 są tylko dalszym ciągiem roku 1968"31.

28 Wystąpienie W. Gomułki, I sekretarza KC PZPR, z 18.09.1964, zob. Maszynopis ze Zjazdu ZLP w Lublinie, 18-21.09.1964, s. 61.

Zob. M.C. Steinlauf Pamięć nieprzyswojona. Polska pamięć Zagłady, przeł. A. Tomaszewska, Wydawnictwo Cyklady, Warszawa 2001.

A. Osiecka, Szpetni czterdziestoletni, Wydawnictwo Iskry, Warszawa 1985, s. 112.

A. Rudnicki Sto lat temu umarł Dostojewski, Wydawnictwo Literackie, Kraków 1989, s. 45. 
W ten sposób „zawstydzone imaginarium” Nowej Huty zamyka się hasłami bardzo przypominającymi socrealistyczne początki, jak wiadomo - narodowe w formie, socjalistyczne w treści. Aktywiści partyjni (kasza ze skwarkami), zebrani w marcu 1968 na jedynie słusznej demonstracji w Sali Kongresowej Pałacu Kultury i Nauki (do niedawna im. Józefa Wissarionowicza Stalina), protestują przeciw panoszeniu się w Polsce Ludowej inteligencji, która zapomniała o swoim pochodzeniu, dzieci czerwonej burżuazji oraz elementów ideowo nam obcych. Niosą transparenty: „Literaci do pióra”, ,Syjoniści do Izraela”.

A następne imaginarium otwiera już brama Stoczni Gdańskiej, z napisem „Solidarność".

\section{Abstract}

\section{Andrzej Zieniewicz}

UNIVERSITY OF WARSAW

The Sensitivity and Hostility of Transformations: Migration, Land Reform and Socialist Realism in the Context of the 'Revolution we Slept Through'

The beginning of the Polish People's Republic was marked by three real as well as symbolic processes: land reform, migration and the socialist realist cultural programme. But the difficulty of locating these transformations in the imaginary field is not only a question of 'having slept through' these events (Andrzej Leder), but also a question of a forced awakening, indeed one of a necessary change in the autobiographical project, an approbation (imposed on ourselves) for 'becoming someone else'. This is about the experience where the level of historical reality directly translates into individual biography, and this $i$ an experience of a liminal nature. The peasant who acquired land with the reform and the migrant who was brought to settle a given area - they emancipated themselves and attaining subjectivity, but above all, they did so as beneficiaries, participants and advocates of the socialist authorities. They both owned the place where they lived, but this'private property' existed thanks to the superior structure of the state and the historical and political changes of which it approved.

\section{Keywords}

migrations, socialist realism, land reform,'awakening', self-description 